\title{
DEZ REFLEXÕES REPUBLICANAS II/2013
}

\author{
Flávio R. Kothe ${ }^{1}$
}

\section{I - COPA DAS CONFEDERAÇÕES E CAPA DA FEDERAÇÃO}

O Brasil esteve vivendo, ao mesmo tempo e não por acaso, a Copa das Confederações de futebol e as maiores demonstrações de rua dos últimos vinte anos. Os governantes e a mídia pareciam tomados de surpresa. Não se esperava que isso fosse acontecer. Há inabilidades óbvias de governantes, que, em vez de esperarem mais um mês, permitiram aumentos de passagem exatamente quando está havendo uma copa, que expõe o país às vistas do mundo inteiro. O problema é, porém, mais grave que um esperto cronograma administrativo.

Trata-se de saber se realmente convinha investir tanto recurso público em estádios, algo tão menos necessário do que transporte público, escolas, hospitais. Se o Brasil tivesse já resolvido esses problemas básicos, não se seria contra fazer arenas para espetáculos. Quando o Brasil estava bem de finanças, houve um grave erro de avaliação: em vez de aproveitar o período para construir metrôs, ferrovias, escolas e hospitais, em vez de fazer o serviço público funcionar nos padrões do primeiro mundo, o governo decidiu, sem perguntar ao povo, comprometer o país com obras faraônicas, de uso muito ocasional e limitado. Não basta pão e circo ao povo. Os tempos são outros.

Foram atendidos os interesses de donos de hotel, de restaurantes, de construtoras, de jogadores e jornalistas, mas não se atenderam às demandas básicas da sociedade. Por todas as cidades médias e grandes, a cada dia tem-se o espetáculo deprimente de grandes engarrafamentos por todo canto, e não mais apenas nos horários de pique. Os carros ficam gastando gasolina inutilmente, as pessoas perdem tempo, os acidentes se acumulam. A Petrobrás não consegue atender à demanda crescente de gasolina, suas contas e as do país se desequilibram desfavoravelmente. Os problemas se acumulam por não ter havido o encaminhamento correto no momento certo. Será que é tarde ou é preciso uma mudança de rumo?

Várias tendências mudaram. Nos tempos do Brasil Colônia e Império, quando a Igreja era parte do Estado, boa parte do esforço coletivo era dedicada a construir templos, pois se dizia que era preciso orar para garantir uma vida eterna. Essas crenças estão desaparecendo. Em países como Holanda, Alemanha e Inglaterra, milhares e

\footnotetext{
${ }^{1}$ Flávio R. Kothe é professor titular de estética na Universidade de Brasília.
} 
milhares de igrejas estão sendo fechadas e vendidas por falta de fieis. Elas são demolidas ou transformadas em restaurantes, pistas de patinação, locais de shows. Ainda não se chegou a isso no Brasil.

Chegou-se, porém, a investir uma parte significativa do esforço coletivo na construção de "arenas" para jogos de futebol e shows. Em vez de cultuar a salvação da alma, tem-se tratado de cultivar o corpo. Em vez de admirar uma alardeada santidade, admira-se o jogador, com suas habilidades físicas. Algo mudou. Está em curso um processo de laicização inexorável. Não se chegou, no entanto, à razão.

Mentiu-se dizendo que para a Copa Mundial seriam resolvidos os problemas do transporte coletivo e dos aeroportos. Quase nada foi feito. Pelo que se fez nos estádios, deixaram-se de fazer muitos quilômetros de metrôs e ferrovias, que seriam úteis e necessários a cada dia, para muitos milhões de brasileiros. O concreto teria sido mais bem empregado nisso. Lula fez um grave erro de avaliação. Dilma tornou-se refém do compromisso assumido pelo antecessor. Não ousou tomar outro rumo. Os partidos de oposição não souberam antes nem depois oferecer caminhos alternativos. Os conservadores seriam, em geral, mais uma regressão do que uma solução para a integração crescente de milhões de brasileiros ao mercado.

Muitos se perguntam se adianta agora fazer demonstrações, quando o dinheiro já foi gasto, os estrangeiros estão aí, uma copa está em andamento e a outra há de vir inexoravelmente. Não seria isso uma descortesia com os visitantes? O que está à prova é se o país é uma democracia ou se, como registrou Machado de Assis, ele é uma oligarquia absoluta, não importando o regime e o partido no governo.

Por que se demorou tanto a perceber que havia uma profunda insatisfação que circulava nas conversas particulares, mas não tinha espaço na mídia nem nos parlamentos? A "imprensa livre" é sustentada por verbas governamentais, propaganda e merchandising; só escrevem os jornalistas de acordo com as editorias. Faltam estadistas na política. $\mathrm{O}$ espaço público na mídia não é proporcional à competência intelectual. $\mathrm{O}$ país, gerado sob o espírito autoritário da Contrarreforma, não tem uma tradição de debate. Faz parte da cortesia brasileira não discordar. Momentos democráticos foram até hoje exceção, não regra. Mesmo quando há algum debate na tevê, os debatedores escolhidos pertencem ao espectro da direita.

Pensou-se, porém, que bastaria ao povo mais circo. As promoções culturais dos governos não melhoram em geral o gosto popular, mas apenas reiteram o gosto parco de um povo pobre. Kant dizia que os governos não querem pessoas que pensem por sim, 
mas que obedeçam. Os funcionários públicos são chamados de servidores. São servos que devem obedecer, andar no passo do paço.

Estamos habituados à propaganda, que é um compromisso com a meia verdade, portanto com a mentira e meia. Ela não se compromete a dizer toda a verdade, doa a quem doer. Não é com publicidade que se chega ao bem público.

Diz-se que todo o poder emana do povo. Isso ainda precisa ser provado. Para discernir o que é o bem comum, é preciso um compromisso radical com a verdade. Ela precisa da liberdade para existir. Estamos em tempos de provação.

\section{II - DA DEMOCRACIA REPRESENTATIVA}

A democracia se funda na suposição da igualdade de todos os seres humanos, embora se perceba, ao se olha de perto, que sua igualdade é a de todos serem diferentes. Quanto mais de longe de olha, mais iguais se tornam. A igualdade parece resultar de uma falta de acurácia no olhar, enquanto as diferenças parecem resultar da ênfase a dessemelhanças que poderiam, de outra perspectiva, passar despercebidas. As cláusulas pétreas das constituições são como traumas neuróticos: pontos problemáticos, nos quais não se quer tocar. As demonstrações de rua recentes no Brasil colocaram em questão a democracia representativa. Com o desenvolvimento da internet, decisões políticas básicas poderiam ser tomadas pela população, cabendo à casta política apenas fazer os detalhamentos, em vez de ser, não importa qual o regime, instrumento da minoria para sugar em proveito próprio o trabalho da maioria.

As aristocracias baseavam-se na crença da desigualdade inata dos homens. Entre os gregos, acreditava-se que os aristocratas tinham sangue divino, por serem descendentes de algum deus ou deusa, o que lhes daria atributos superiores e o direito a governar, ter gado, cidades e gente. Esse "sangue azul" derivava de relações sexuais entre seres que se distinguiam por serem mortais os humanos e imortais os deuses. De resto, eles se pareciam muito, no aspecto físico e no modo de ser. O Olimpo era um espaço reservado a deuses belos. Os feios estavam condenados às forjas dos vulcões ou eram expulsos. Nesse paradigma, não haveria espaço para um Cristo crucificado. Os deuses eram vitoriosos, ainda que alguns pudessem sofrer derrotas ocasionais.

O cristianismo se propagou, na Roma antiga, com sua ética antitética à do patriciado, como religião dos escravos, que se sentiram valorizados por crerem ter uma alma imortal, serem criaturas de Deus, irmãos em Cristo, descendentes de Adão e Eva. Ainda que se diga que democracia se baseia na crença nessa igualdade e que o 
socialismo quis tornar a igualdade um fato social e não apenas um formalismo jurídico, fica difícil explicar como o cristianismo conseguiu conviver durante vinte séculos com a desigualdade social, tendo a Igreja Católica apoiado aristocracias, monarquias, ditaduras e escravismos. Apoiava e era apoiada por. Quando a democracia reina, ela se diz democrática. Sendo uma instituição muito rica, ela se diz a favor dos pobres. Ela não é, contudo, a única a ser contraditória.

O capitalismo americano se diz democrático, mas de fato é plutocrático: os presidentes, os juízes do Supremo Tribunal, os senadores, a grande maioria dos deputados - todos são milionários. Ser milionário é pouco, porém. A diferença entre uma pequena minoria de bilionários e a grande massa que mal tem o que comer é crescente. Os mais pobres não são os operários sindicalizados, e sim os desempregados. Na China, o governo se diz comunista, mas o congresso do povo é dominado por empresários que são multimilionários.

As tensões sociais não param de aumentar por toda a parte. Já não se sabe mais o que é conviver numa sociedade em que todos tenham basicamente o mesmo e, por isso, não precisem ficar roubando uns dos outros. Isso é possível, já existiu, mas está se tornando novamente uma utopia.

\section{III - DA DEMOCRACIA REPRESENTATIVA}

A democracia se funda na suposição da igualdade de todos os seres humanos, embora se perceba, ao se olha de perto, que sua igualdade é a de todos serem diferentes. Quanto mais de longe de olha, mais iguais se tornam. A igualdade parece resultar de uma falta de acurácia no olhar, enquanto as diferenças parecem resultar da ênfase a dessemelhanças que poderiam, de outra perspectiva, passar despercebidas. As cláusulas pétreas das constituições são como traumas neuróticos: pontos problemáticos, nos quais não se quer tocar. As demonstrações de rua recentes no Brasil colocaram em questão a democracia representativa. Com o desenvolvimento da internet, decisões políticas básicas poderiam ser tomadas pela população, cabendo à casta política apenas fazer os detalhamentos, em vez de ser, não importa qual o regime, instrumento da minoria para sugar em proveito próprio o trabalho da maioria.

As aristocracias baseavam-se na crença da desigualdade inata dos homens. Entre os gregos, acreditava-se que os aristocratas tinham sangue divino, por serem descendentes de algum deus ou deusa, o que lhes daria atributos superiores e o direito a governar, ter gado, cidades e gente. Esse "sangue azul" derivava de relações sexuais 
entre seres que se distinguiam por serem mortais os humanos e imortais os deuses. De resto, eles se pareciam muito, no aspecto físico e no modo de ser. O Olimpo era um espaço reservado a deuses belos. Os feios estavam condenados às forjas dos vulcões ou eram expulsos. Nesse paradigma, não haveria espaço para um Cristo crucificado. Os deuses eram vitoriosos, ainda que alguns pudessem sofrer derrotas ocasionais.

$\mathrm{O}$ cristianismo se propagou, na Roma antiga, com sua ética antitética à do patriciado, como religião dos escravos, que se sentiram valorizados por crerem ter uma alma imortal, serem criaturas de Deus, irmãos em Cristo, descendentes de Adão e Eva. Ainda que se diga que democracia se baseia na crença nessa igualdade e que o socialismo quis tornar a igualdade um fato social e não apenas um formalismo jurídico, fica difícil explicar como o cristianismo conseguiu conviver durante vinte séculos com a desigualdade social, tendo a Igreja Católica apoiado aristocracias, monarquias, ditaduras e escravismos. Apoiava e era apoiada por. Quando a democracia reina, ela se diz democrática. Sendo uma instituição muito rica, ela se diz a favor dos pobres. Ela não é, contudo, a única a ser contraditória.

O capitalismo americano se diz democrático, mas de fato é plutocrático: os presidentes, os juízes do Supremo Tribunal, os senadores, a grande maioria dos deputados - todos são milionários. Ser milionário é pouco, porém. A diferença entre uma pequena minoria de bilionários e a grande massa que mal tem o que comer é crescente. Os mais pobres não são os operários sindicalizados, e sim os desempregados. Na China, o governo se diz comunista, mas o congresso do povo é dominado por empresários que são multimilionários.

As tensões sociais não param de aumentar por toda a parte. Já não se sabe mais o que é conviver numa sociedade em que todos tenham basicamente o mesmo e, por isso, não precisem ficar roubando uns dos outros. Isso é possível, já existiu, mas está se tornando novamente uma utopia.

\section{IV - CUIDADOR DE IDOSOS}

Sófocles propôs, na peça Ajax, a tese de que os homens são fundamentalmente iguais porque são todos frágeis diante da doença grave e da morte. Faltou dizer que todos nascem frágeis, dependentes de outros humanos, mais velhos, para sobreviver tanto física quanto psiquicamente. Gera-se como que um processo de retribuição, em que aqueles que foram cuidados passam depois a ter de cuidar daqueles que deles cuidaram. Supor que esses cuidados sejam uma espécie de investimento, a render juros 
e correção monetária com o correr dos anos, pode se tornar uma decepção. Não é por alguém ter recebido muitos cuidados que ele se sente obrigado a retribuir. A generosidade não é proporcional ao que se recebe. A gratidão é uma rara pedra preciosa. Quando uma dívida é alta demais para ser paga, tem-se a tendência de renegá-la, a pretexto de ser um direito adquirido. Ninguém pediu para nascer, mas isso não dá direito a cobranças infinitas.

Há aqueles que na difícil e inevitável hora da morte são mais corajosos que outros. Um capelão católico francês, que atuou nas guerras mundiais, deu o interessante testemunho de que, entre os soldados agonizantes, os que não acreditavam na vida após a morte se mostravam mais conformados com a inevitabilidade da morte do que aqueles que tinham passado a vida acreditando numa vida após a morte, como se estes tivessem evitado se defrontar, pelo sistema de crenças, com o destino de todo ser vivo: a morte. Ela não é monopólio do homem. Os animais também têm medo de morrer.

A religião grega estabelecia como distinção básica entre homens e deuses que estes seriam imortais. $\mathrm{O}$ cristianismo prometeu a imortalidade a todos, tornando todos divinos, e isso agradou a muitos. A lógica da crença não está nela, mas no que a motiva. Cada um gostaria de ser tão precioso que pudesse ser preservado ad aeternum, para exaltar a glória de uma divindade carente de adoração. Querer argumentar que isso seria um misto de narcisismo e megalomania de nada convence a quem tem na crença uma promoção que a vida real não lhe dá.

A sociedade moderna tende a ter um aumento da longevidade e uma diminuição da taxa de natalidade, o que faz com que ela tenha cada vez mais idosos a depender de pessoas mais jovens quando já não podem mais cuidar de si mesmos. Em geral os jovens querem é cuidar da própria vida, não cuidar dos idosos. Com o culto ao novo, pouco impera a cultura do respeito pelo idoso. Ela está sendo imposta à força por lei. Não se vê no idoso uma pessoa mais sábia e sim antes um caduco, que está atrapalhando a vida dos outros. Muitos morrem de desgosto.

Se há cada vez mais velhos, cada vez mais longamente idosos, como convencer jovens a se dedicarem a cuidar deles? Não se está falando aqui daqueles que, cuidando dos necessitados, acham que garantem um terreno no céu: esses fazem um investimento, no qual, em troca de um labor finito, acreditam que irão obter uma recompensa infinita. Nos países ricos, como Suíça ou Alemanha, se importam cada vez mais pessoas de países menos ricos para cuidarem dos velhos depositados em asilos. No Brasil, a nova 
lei da empregada doméstica vai abranger os cuidadores de idosos, com todos os seus adicionais noturnos e fins de semana trabalhados.

Um(a) enfermeiro(a) que cuida de um doente ou de um acidentado espera que ele, após alguns dias ou algumas semanas, se recupere e retome a vida normal, produtiva. Assim, seu trabalho tem sentido. Quem cuida de idosos vê a decadência física e mental se alastrando mês após mês, sem ter a expectativa de que esse processo realmente possa se reverter: é preciso ser forte para suportar o fracasso inevitável. Caso não se invista o esforço dos sãos no cuidado dos idosos e doentes, resta apenas regredir à eliminação de quem não seja útil à sociedade. Até onde vai esse critério? Todos podem ser considerados substituíveis e até inúteis. Ainda que a lógica da economia seja a produção de bens úteis, o mais importante na vida está além do horizonte da utilidade imediata.

Nem sempre a família pode tomar conta do idoso. Precisa contar com outras pessoas. As escolas e o Estado não estão cuidando suficientemente da profissão de cuidador de idosos. Há uma carência crescente de milhares de profissionais. Quem optar por essa profissão, terá emprego certo.

\section{V - DO IGUAL E DO DIFERENTE}

Mãe de cinco filhos, uma avó me disse mostrando a mão: "Olha essa mão. Da mesma palma saem cinco dedos, e cada um é diferente dos outros. Assim também é com os filhos." Para quem olhar de perto, os dedos são bem diferentes; quando olhados de longe, os detalhes desaparecem e tudo parece igual. Quando estamos dominados por problemas do cotidiano, é bom olhar a noite estrelada, para ver como eles encolhem enquanto descobrimos nossa pequenez e fragilidade.

A matemática, que dá fundamento às ciências exatas, iguala o semelhante e esquece a diferença. Dois ninhos com dois ovos cada não são o mesmo que um ninho com quatro ovos, mas para a matemática $2+2=4$. Ela reduz a realidade ao quantitativo, esquece a qualidade e que nem sempre uma quantidade igual é equivalente. A origem grega do termo "matemata" significava aquilo que se pode entender e transmitir. Como o mais fácil de contar é a contagem, "matemata" virou matemática, a lógica formal dos números. Até Deus nos tempos modernos deixou de ser sarça ardente e uma figura antropomórfica para se tornar a infinitude, um símbolo matemático.

Nietzsche dizia que quando se soma um homem e uma mulher, muitas vezes o resultado pode ser três ou quatro (como poderia ser um, zero ou oito). A lógica formal 
numérica gera contradições. A diferença entre um e zero parece um, mas, olhando mais de perto, há uma infinidade de números possíveis entre ambos, de maneira que teríamos que um é igual a infinito. Se ampliarmos o número de lados de um polígono, quando se chegasse à infinidade de lados teríamos uma esfera, que já não tem mais lado nenhum, de maneira que se teria infinito igual a zero. Seria possível supor também que a esfera tem dois lados, o de fora e o de dentro, e zero seria igual a dois e a infinito.

Supõe-se que as ciências humanas sejam menos exatas que as exatas. Como estas se fundam na inexatidão matemática, talvez se deva ouvir a convicção de artistas de que, ao comporem uma obra, embora partam de uma multiplicidade de possibilidades, quanto mais avançam o trabalho mais ficam convencidos de que só há um modo certo de fazer um traço, colocar uma cor, escrever uma palavra. Há um rigor na arte que é tão exigente quanto um cálculo de estrutura. Quando não é cumprido, a obra sucumbe ao seu projeto. Mesmo no jogo de xadrez, sempre há uma jogada que acaba se mostrando melhor que qualquer outra possível.

Alberti dizia que uma arquitetura perfeita é aquela em que não se pode tirar nem acrescentar nem mudar nada sem que o resultado se torne pior do que a obra que aí está. Isso depende, porém, da tecnologia possível. Quando ela muda, novas execuções se tornam possíveis. O que é do gosto de um tempo e lugar se torna absurdo para outro.

É preciso haver abertura para diferentes modos de encarar as coisas. Há modos diversos de raciocinar. Por mais que se procure acertar, cometem-se erros. Muitas vezes os piores erros são cometidos quando há um máximo de preocupação em acertar. Não se conhecem nunca todos os fatos presentes nos fatos nem se podem antecipar todas as consequências de decisões. Pode haver até acertos no erro, como há erros em acertos.

A democracia se baseia no princípio da igualdade entendido como igualação de todos. Na teoria, hoje não existe mais voto qualificado pela riqueza; na prática, há eleitores que valem mais. O princípio da igualdade poderia ser entendido, porém, como o reconhecimento da desigualdade do desigual, com o direito da diferença ser diferente. Havendo tolerância com a diversidade, o resultado geral é uma riqueza maior do que se uma parte eliminar as diferenças do resto. A democracia envolve uma nova compreensão do que seja a verdade: não mais a autoridade de um, mas um exercício da liberdade da coisa aparecer como ela é e o sujeito permitir que isso apareça para ele. 


\section{VI - MORTE ASSISTIDA}

Não só por ser o Brasil um país de formação católica, mas por ser um tema singularmente difícil e desagradável, não se tem tido um debate público, que é corrente na Europa Ocidental, sobre o direito à morte assistida. Será a vida um direito ou uma obrigação? Sob o pressuposto de que ela seja um direito, acaba-se fazendo dela uma obrigação. O Estado é obrigado a zelar, por exemplo, para que um preso não se suicide na cadeia. Então a vida é uma obrigação.

Se o cidadão tem na vida um direito personalíssimo, como o nome e a identidade, ele deveria ter também o direito de abdicar desse direito, dizendo que não quer mais viver. Na prática, é isso o que fazem os suicidas, e ninguém tem nada a dizer ou fazer. A religião católica e a judaica punem esses mortos proibindo que sejam enterrados no cemitério. Para o morto isso não faz diferença: punem-se os familiares, como se fossem culpados. Eu tenho um tataravô, que se suicidou por não aguentar as lembranças da Guerra do Paraguai, perdido até hoje no meio do mato: faziam uma cova rasa debaixo do galho em que estava a corda e deixavam cair o corpo. Optar por viver ou não faz parte da liberdade do cidadão. O Estado não pode decidir por ele, assim como o Estado não pode decidir por sua morte, ao menos não, oficialmente, em países nos quais não há a pena de morte.

Geralmente os suicidas não têm liberdade. Estão eles de tal maneira assolados por um aspecto da vida que confundem essa parcela com a totalidade. Eles são dominados por uma sinédoque, que eles nem sabem qual é. Não têm domínio sobre si, portanto não estão exercendo a liberdade. O impulso para a morte é neles mais forte que o instinto vital.

Freud propunha a tensão entre "Eros" e "Thanatos", o impulso de vida e o impulso de morte. Nas batalhas da vida parece prevalecer o primeiro, mas com a vitória final do segundo. O homem quer que essa derrota seja uma vitória. Prefere ir para o inferno a não ir para lugar nenhum depois de morto. Os que abusam de drogas e bebida a pretexto de aproveitar a vida estão, de fato, se destruindo aos poucos: são suicidas acovardados.

Na Antiguidade clássica, um guerreiro que agisse contra a sua coletividade, um general que perdesse uma grande batalha, um governante que visse o seu palácio invadido pelo inimigo, todos se sentiam no dever de se suicidar ou pedirem a um amigo que o liquidasse. Hércules, ao não mais suportar a dor de se ver queimando vivo, pediu ao filho que o matasse; tendo o filho se recusado a fazê-lo, o herói deu seu arco e suas 
flechas infalíveis a quem se prontificou a auxiliá-lo na eutanásia. O suicídio era visto aí como ato de grandeza, uma prova de virtude. Em geral, os suicidas não são dignos dessa virtude antiga.

Em vários países europeus já existe o direito de o cidadão deixar disposto que, em circunstâncias extremas, sua vida não seja mantida artificialmente por aparelhos ou que, em caso de doença grave irreversível e dores insuportáveis, ele tenha o direito à morte assistida. Uma junta médica faz a avaliação do paciente, para decidir se ele deve ser aliviado definitivamente dos sofrimentos. Aqui o médico seria criminalizado. Por menos que se queira fazer uso dessa possibilidade, para muitos é um consolo pensar que, numa situação sem retorno, ele possa deixar disposto contar com esse auxílio.

A vida que temos é a única certeza que temos. Certo é também que iremos perdê-la. Vida sem nenhuma qualidade não vale a pena ser vivida. Ela pode se tornar um fardo tão pesado que morrer se torna um alívio para todos. Nem os que acreditam numa vida após a morte costumam ter a coragem de se tornarem mártires para ganhar o céu nem gostariam de usar uma doença grave para, com todos os ritos, se encaminharem para a eternidade.

No convento cisterciense de Bad Doberan, na beira do Báltico, os monges medievais viviam apenas de 22 anos em média. Faziam grandes jejuns, madrugavam para orar e laborar. Em compensação, bebiam três a quatro litros de cerveja por dia. Tanta cerveja em estômago ralo permite ver aparições celestiais entre os hinos. O céu, nessa concepção, tinha lugar para muitos. O importante não era viver, e sim salvar a alma.

Nós procuramos médicos e tratamos de cuidar do corpo, pois sabemos que a mente é atividade cerebrina. Não estamos em geral dispostos a nos embalar na crença de que uma religião nos religa ao céu e nos evita os quintos do inferno. Quer se assuma isso ou não, na prática, na prioridade entre o céu e a terra, entre o infinito e a finitude, opta-se pelo segundo termo, esperando que se converta em alguma forma do primeiro.

Nessa época de grandes catequeses, quer se queira ou não, está-se vivendo o que a tradição filosófica de Hegel e Nietzsche tem chamado de "morte de Deus". Hegel queria dizer com isso que, ao olhar ao seu redor, em Berlim há duzentos anos, percebia que a religião já não desempenhava função básica nas decisões e no modo de existência das pessoas. Nietzsche levou mais longe, falando da reversão de todos os valores, a partir de uma revisão radical da visão de mundo. 
FLÁVIO R. KOTHE

Em países como Inglaterra, Holanda e Alemanha, milhares de igrejas estão sendo desmontadas e vendidas simplesmente por falta de fieis. Muitas estão sendo convertidas em restaurantes, ringues de patinação, casas de espetáculos, moradias. Os objetos de culto estão sendo vendidos para países do leste europeu. Dessa perspectiva, o espetáculo de milhões de fieis na praia querendo sentir de perto de Deus tende a ser visto como demonstração de atraso coletivo que de progresso da razão crítica. Embora os crentes estejam buscando seu aperfeiçoamento, será que não estão reforçando o dogmatismo?

\section{VII - IN GOT WE TRUST}

Nos dólares americanos está escrito: "In Got we trust", em Deus confiamos. O que tem Deus a ver com a nota de dinheiro? Será ele quem valida todas as relações entre as pessoas, dá um retorno imediato como uma nota de dinheiro? Soa estranho que os homens esclarecidos que fundaram os Estados Unidos tenham apelado para um Deus que os iluministas e cientistas do século XVIII normalmente dispensavam como hipótese para explicar o universo. No máximo aceitavam que a religião era um mal necessário porque a maioria da população não saberia se comportar bem sem ter a ameaça de um inferno e uma divindade disposta a punir os pecadores.

De que Deus se está aí falando? Ainda que os católicos tenham sido uma minoria entre os americanos, parece que se está falando de um Deus-Pai cristão, que descende de Jeová, mas não é o mesmo, pois este não tinha filho e era só de um povo. Também não é o Deus de Maomé. Parece não ser o Jesus dos sentimentos fraternos nem o Espírito Santo a iluminar os espíritos e propor uma nova era para a humanidade, a suceder o mundo cristão, o império de Cristo. Se os pais da pátria eram maçons, esse Got seria o arquiteto do universo, um deus de novo diverso.

Em 1968, numa palestra dada no Centro Acadêmico da Faculdade de Direito da UFRGS, o palestrante, que era de origem judaica, foi violentamente atacado por membros da comunidade judaica de Porto Alegre, porque havia postulado a tese de que Israel era o braço armado dos Estados Unidos na região. Eu não sei se Israel é um protegido dos Estados Unidos ou se estes são dominados por ele: o Got das notas seria então antes Jeová do que Deus-Pai. Talvez convenha a confusão. Na fala de Obama na ONU, foi impressionante o seu tom imperial. Ele negocia só se quiser.

Os americanos têm procurado se apresentar como campeões da liberdade e da democracia, mas encheram a América Latina de ditaduras que desgraçaram mais de 
uma geração. Em todos os cantos do planeta, eles se metem na vida de outros países, sem respeitar sua soberania, sua capacidade de decidir internamente qual o governo que lhe serve. Eles constroem porta-aviões e foguetes intercontinentais caríssimos, estão mantendo bases militares há dezenas de anos no Japão, na Espanha, na Alemanha e assim por diante, como se tivessem sido convidados. É de se ficar admirado que eles tenham saído de suas bases no Nordeste brasileiro.

O governo americano se dá o direito de intervir em qualquer país cujo governo não lhe agrade, de enviar seus drones fazendo matanças onde quer que suspeitem poder haver um suposto inimigo, de espionar o que qualquer pessoa, em qualquer parte do planeta, escreva ou pesquise em seu computador. Suas embaixadas estão recheadas de agentes de informação disfarçados de diplomatas, a National Agency of Information tem mais de 40 mil funcionários e consegue armazenar e avaliar tudo o que passa pela internet. Estamos protegidos diante disso? Seguramente não. Se um par de adolescentes fizer uma brincadeira de mau gosto sobre bombas e atentados, sua segurança estará a perigo, onde quer que estejam. A espionagem na Petrobrás mostrou que é apenas uma desculpa esfarrapada dizerem que só buscam informações para evitar atentados. O monopólio de informações é uma garantia de poder para o Estado.

$\mathrm{Na}$ geração dos jovens americanos que se recusaram a ir como soldados para a guerra do Vietnã, muitos tiveram de emigrar para outros países ou viver como clandestinos para não serem presos. Há alguns anos consegui uma lista de pessoas com o meu sobrenome e que haviam emigrado da Alemanha para os Estados Unidos. Numa família pequena, havia mais de trinta homens que haviam morrido nas várias guerras dos americanos: Primeira Guerra, Segunda Guerra, Camboja, Vietnã. Hoje a lista seria ainda maior, com as guerras que a indústria armamentista americana fica inventando para ter mais lucros. O orçamento militar americano é maior que os dez maiores seguintes juntos. O povo da Silésia, origem da família, foi extinto com a política de Hitler.

O que representa Got, para que se possa confiar nele? Ele representa a vontade de saber tudo, de estar em toda parte, de poder tudo. O conceito de onipotência contém uma contradição interna, pois o poder é a capacidade de se sobrepor a resistências. Um ser onipotente, a quem nada nem ninguém há de resistir, não pode ter noção de quanto poder ele próprio tem. O saber é um esforço para vencer a ignorância: quem já sabe tudo, não tem nenhuma ignorância a superar. Ele não pode sequer saber o que sabe, o que o torna autocontraditório. O saber sempre é limitado. Quem está por toda parte tem 
FLÁVIO R. KOTHE

de ser tudo o que há, não pode ficar fora de nada que existe. Se ele é tudo, ele é alguém que não é ninguém: um ser onipresente não consegue sair de si, se torna o seu próprio prisioneiro. Ou ele é o universo inteiro, ou está fora dele. Se estiver fora, não pode ser infinito, pois seria ele menos o universo; se for o universo, cai-se no panteísmo de que tudo é divino e maravilhoso. Essa discussão já tem mais de duzentos anos na filosofia.

Os americanos declaram confiar em Deus, mas construíram a confiança só em si mesmos: dão-se ao direito de bisbilhotar tudo, serem oniscientes; se meter por toda a parte, serem onipresentes; impor sua vontade onde quiserem, serem onipotentes. Eles querem ser Deus. Tendo alcançado a hegemonia sobre a Terra, o planeta já não lhes basta. Querem o universo inteiro. Só que este é infinito, não uma elipse que dá volta sobre si e que se poderia controlar. Em quem quer ser Deus não se pode confiar.

\section{VIII - NA CATEDRAL DA SAGRADA FAMÍLIA}

Quando cometemos um erro, geralmente não o percebemos como erro. Há quem faça o errado de modo intencional, mas costuma então inventar um jeito de torná-lo um acerto. A vida é má: ela sobrevive da morte da vida alheia. Há muito a filosofia diz que o homem é mau por natureza; o marxismo achava que ele se torna malvado pela má sociedade de classes, bastando corrigi-la para que nele aparecesse um anjinho a bater asas. As religiões cristãs acham que o homem nasce mau, com o pecado original, mas que com água miraculosa e algumas palavras mágicas ele vira a promessa de um santo. Todos estão se comovendo com as fotos do herdeiro do trono inglês sendo batizado.

Que se queira acertar não evita, no entanto, as sequelas do erro que foi feito com as melhores intenções. Por isso se diz que de boas intenções o inferno está cheio. Seria bom se assim fosse: um morto é que teria de pagar a dívida. Elas tornam, porém, um inferno a própria vida do bobo bem intencionado.

Quando alguém cobra um pênalti, logo percebe se a cobrança foi mal feita, mas ele não pode mais fazer nada. A bola continua voando para onde não deveria. Resta a esperança de que em outra ocasião o resultado seja melhor. De boas intenções se faz um céu. Quanto maior, mais ele pesa sobre o sujeito, esperando ser alcançado.

O herói trágico é um bom sujeito, que quer fazer tudo certo e, quanto mais se esforça, mais cava a própria cova. Nas execuções sumárias em operações bélicas, condenados a morte foram muitas vezes forçados a cavar a própria cova. Se o sujeito vai morrer de qualquer modo, será que ele deve ainda facilitar a vida do carrasco ou o mínimo de dignidade seria se recusar a fazê-lo? Cavar a cova pode retardar a execução, 
alimentar a ilusão de que uma legião de anjos ou uma cavalaria venham trazer a salvação. Não adianta dividir cada momento em dois, para provocar a infinitude do tempo: o relógio é inexorável, o carrasco tem mais coisas a fazer.

Dito em outros termos: a criança que era forçada a buscar a vara com que seria açoitada pelo pai ou pela mãe, deveria ela recusar-se a fazer isso, e apanhar dobrado? De quem ela poderia esperar socorro? Da avó, do tio, do juiz, da polícia? Ninguém se metia. Havia na minha região natal reproduções baratas da tela A última ceia, de Leonardo da Vinci, atrás da qual ficavam as varas de marmelo ou pereira, para dizer que naquela casa família e ordem eram sagradas. Nas colônias alemãs do Sul, já em 1849 a escravidão estava abolida. Como os colonos tinham cavalaria, os ulanos, e infantaria, os escravos das fazendas ao sul do Jacuí fugiram para o meio deles. Como quem não trabalha também não come, os colonos, não tendo escravos, tinham atitudes de quem escravizou os filhos. Não podiam vendê-los nem matá-los, conforme previa o Direito Romano, mas decidiam até casamentos. Quando criança eu mesmo vi amiguinhos sendo açoitados por não terem "feito a obrigação". Brincar não era propriamente um direito.

Quando em agosto de 2013 visitei a Catedral da Sagrada Família projetada e construída por Gaudí, em Barcelona, estranhei que ninguém estranhasse o sagrado dessa família: o pai não era o pai (daí que José, no México, vira Pepe, de pater praesumptus, PP, o pai presumido, como se registrava nos catecismos para não esquecer que Jesus era filho de Deus), a mãe não havia sido fiel ao marido (que não podia ter intimidades com ela, donde que) e, a essa altura do campeonato, o filho era...

Nietzsche disse que como Deus tudo pode, não precisaria cumprir os próprios mandamentos. Faltou anotar que Jeová também já não havia cumprido o primeiro mandamento, aquele que diz que ele ficaria muito zangado com quem não respeitasse as crianças e proibia ainda que se fizesse escultura ou imagem de qualquer ente que estivesse na água, sobre a terra ou nos ares: ele próprio mandou fazer, poucos depois, a escultura de uma serpente para curar picadas venenosas. Afinal, vacinas nem sempre são eficazes e às vezes, por um bem maior, é preciso rever o que se disse.

$\mathrm{Na}$ catedral, após pagar vinte euros de entrada para cada um de nós, fiquei pensando com meus botões, enquanto junto com um médico socorria uma estudante da UnB que, sob o sol inclemente, havia desmaiado ao meu lado na imensa fila da entrada: como se justificaria essa construção quando se espera que a arte transmita a verdade? Qual era sua verdade? Se o modelo de família era esse, nenhum pai poderia querer um filho do qual fosse genitor nem aceitar companheira que lhe fosse fiel. O sagrado é 
modelar e deve ser seguido. Minhas luzes eram fracas, mas a arquitetura era impressionante.

Enquanto eu andava sem luzes em meio às lindas cores advindas dos vitrais, lembrei-me do Evangelho de Maria, considerado apócrifo, em que José, ao voltar de uma longa ausência, encontra a esposa grávida e, indignado, dá-lhe uma surra. Logo depois é intimidado por um enviado do Sumo Sacerdote. Ora, Zacarias havia pecado gravemente: supremo encarregado de manter os preceitos, ele se engraçara com essa virgem do templo. Anjo quer dizer enviado. Para acalmar José, que temia os sacerdotes, Zacarias prometeu zelar pelo herdeiro. Depois ficou mudo por um ano. Anos mais tarde foi assassinado por um grupo de sacerdotes de outra facção. Acabou sobrando para o filho, que poderia tentar unificar o governo sacerdotal com o civil e militar, numa rebelião dos judeus contra o domínio romano. Política, política. Eterno retorno do mesmo.

Ah, a jovem se recuperou bem. Há dias passou por mim lépida e fagueira.

\section{IX - ESPIAR E EXPIAR}

Desde que Snowden denunciou, com abundantes e continuadas provas, a NSA, National Security Agency, ninguém mais pode ignorar que, se usar um celular ou laptop, se acessar um Google ou Facebook, estará sendo captado e capturado em Utah. O que eles lá vão fazer com tanta bobagem que se diz e se escreve, eu não sei, mas devem ter programas para achar agulha no palheiro. Todo mundo pode se sentir observado de perto, como se tivesse a sombra de um ente virtual, não sei se um capeta ou um anjo.

Para quem foi perseguido pela ditadura militar no Brasil, a sensação de estar sendo observado não é nova. Não havendo segredos, diz-se o que se pensa e se pensa o que se diz. A Constituição brasileira garante a liberdade de expressão, mas temos muito ainda a aprender nesse sentido.

Como já estamos perto de celebrar outro cinquentenário, eu estava me lembrando de abril de 1964, quando fui submetido a interrogatório no $8^{\circ}$ Regimento de Infantaria, em Santa Cruz do Sul, minha cidade natal. Eu devia ter 17 anos. Como bom adolescente, eu era um idiota, pois a primeira coisa que me ocorreu dizer ao capitão que chefiava o inquérito foi que eu era menor de idade, como se isso tivesse a menor importância, como se a família estivesse disposta a enfrentar o exército para me proteger. Eu não estava sozinho: havia outros membros da diretoria da UESC, a União 
de Estudantes Santa-Cruzenses. Eu estava lá pagando pecados pretéritos, pois há vários meses nem era mais o secretário de imprensa da entidade.

Quando se está com um guarda armado na porta, fala-se bobagem. Na minha memória - é estranho como ela funciona -, aquele capitão virou mais bigode que gente: o bigode era maior que ele, ele se escondia atrás. Disse que era o chefe do serviço de informações do exército. Eu respondi:

- Mas eu conheço o senhor. Foi meu professor de Biologia, em 1962, no curso de contabilidade, lá no Liceu São Luís. Falava muito sobre o ovo.

O que eu não acrescentei, mas pensei, ao vê-lo meio perturbado, como se eu tivesse dito o que não devia, é que ele não conhecia tanta biologia quanto o professor que eu tinha no científico do Colégio Mauá. No curso - que eu abandonei tão depressa quanto pude, estragando o sonho de meu pai, que queria fazer de mim um contador (de números, não de histórias) -, os colegas estranhavam que se tivesse Biologia em um curso técnico em contabilidade, mas como a vida está em tudo o que se faz...

Passada a primeira reapresentação, o capitão, do bigode, ficou folhando uns papeis e eu fiquei esperando, do outro lado da mesa. Eu tinha escrito alguns artigos para o jornal dos estudantes e para a Gazeta Estudantil, tinha feito um programa de música clássica ligeira aos sábados à tarde na Rádio Santa Cruz, onde também tínhamos um programa estudantil, eu tinha representado a entidade em encontros estudantis em Rio Grande, Passo Fundo, Canela. Como meu pai não havia permitido que eu fosse fazer o curso clássico em Porto Alegre, eu havia ficado vagabundeando, preenchendo o tempo. Em suma, eu havia pecado. Haviam me espiado, era hora de expiar. Eu procurava ao menos respirar.

Ele quis saber de onde eram extraídos os trechos que líamos entre as músicas tocadas na estação. Foi fácil responder. Eram trechos das encíclicas de João XXIII. Eram a palavra do santo padre, o papa. Seria preciso ir prendê-lo em Roma. O bigode engoliu em seco.

Eu achava que só a minha avó, a Grossmutter, lia o que eu escrevia. Mas não! O capitão tinha lido também. Dois leitores! Não só havia lido com acurada hermenêutica, como havia sublinhado diversos trechos, com canetas de cores diversas: preta, azul, amarela, vermelha! Isso me impressionou, eu devia de estar na pior.

O que o capitão queria mesmo saber era quem tem escrito os artigos assinados com o meu nome, quem se escondia atrás do meu nome. Eu fiquei espantado com a pergunta. Fiquei olhando para mim, como se houvesse outro atrás de mim, escondido, 
sem eu saber. Sócrates chamaria isso de daimon, que os romanos traduziram por genius e os cristãos por demônio. Mas eu não tinha nem uma coisa nem outra. Era só eu sozinho.

Fiquei olhando para um artigo em que, se bem lembro, debatia a possibilidade de se criarem grandes empresas estatais, no modelo da Petrobrás, da Fábrica Nacional de Motores e da Vale, para cuidar da produção de bens básicos: Farmacobrás, Nuclebrás e assim por diante. Eu não sabia que os chineses iriam se apropriar da ideia para montar o modo mais produtivo de produção, associando empresas estatais e empresários particulares até ter o partido comunista dominado por capitalistas.

Respondi então:

- Fui eu mesmo que escrevi.

A resposta decepcionou o capitão, que esperava um agente de Moscou e encontrava um agente do Vaticano em um garoto interiorano, um coloninho. Ele ficou folheando para lá e para cá, para ver se formulava a pergunta mais feroz e certeira, no alvo. E disse, afinal:

- O que é que você entende por democracia?

Achei que minha vida estava por um fio. Como meu avô e meu pai tinham me levado a ver muito faroeste no cinema, achei que era hora de a cavalaria americana vir me salvar. E tasquei na lata:

- Como disse Abraham Lincoln, é o governo do povo, para o povo e pelo povo.

Essa resposta foi recitada, ipsis litteris puncte virgulisque, ao pobre datilógrafo, que a marretou numa pobre folha de papel com carbono.

Mais tarde fomos liberados. Ouvi dizer que fomos considerados "inocentes úteis": talvez nem tão inocentes nem tão úteis, mas ainda vivos.

\section{$X$ - DO BEM E DO MAL}

Caçar uma gazela é bom para o leão e mau para ela. Pecado ou virtude parecem depender do lado em que se está. Em A origem da tragédia, Nietzsche mostrou como o conceito de bom provém de "bonus", que eram, na Roma Antiga, as pessoas de tez e cabelos claros, e o de mal provém de "malus", que eram as pessoas de tez e cabelos escuros, os escravos. Bom era ser patrício; mau, nascer escravo. Como hoje.

Kant propôs que a liberdade interior do homem permite que ele possa decidir sobre o modo correto de agir em determinada situação, segundo uma lei que poderia ser formulada racionalmente, devendo ser seguida por todas as pessoas na mesma situação. 
Chamou isso de imperativo categórico. O problema é que quando alguém decide sobre isso em nome da liberdade, ele está interferindo na liberdade do outro, pois talvez não se deva esperar que todos tenham o mesmo tipo de resposta sobre qual seria o modo correto de agir. Dependendo da época, nem concordamos conosco.

Quando de repente uma cobra se atravessa no nosso caminho, o que primeiro fazemos é pular para longe. Não há tempo para formular um julgamento racional: "Eis uma cobra que pode ser venenosa e pode me picar, por isso devo pular para longe dela". Há um saber acumulado no inconsciente, o instinto, transmitido talvez pelo DNA, que permitiu a milhares de gerações de antepassados sobreviverem.

Em geral as pessoas consideram corretos os dez mandamentos trazidos por Moisés, de um senhor que só ele viu. Eles são seguidos porque seriam a vontade de Deus. Então há obediência a uma ordem, não há uma ética pessoal, uma norma a que o sujeito segue por sua livre convicção. Os juízes ao aplicarem as normas também estão obedecendo a uma vontade superior.

Virtude vem da palavra "vir, viris", algo que é próprio do homem, do varão, em sua virilidade. A ética pregada por Cristo, essa de oferecer a outra face e dar preferência aos deserdados da terra, foi a inversão da virtude como era entendida pelo patriciado grego e romano, que não levava desaforo para casa. Estranhamente, nesse sentido as mulheres não poderiam ter "virtude", pois ela é coisa de homem.

Se eu fizer algo bom para outra pessoa, seria aplaudido por ser altruísta; se eu fizer essa mesma coisa para mim, já observou Nietzsche, isso será considerado egoísta, e ruim. $\mathrm{O}$ ato em si seria o mesmo, apenas o destinatário mudaria. Como é que o mesmo ato pode ser considerado uma vez bom e outra vez mau? Se todos cuidassem bem de si, sem incomodar aos outros, a sociedade seria melhor.

Há os que acham que supõem ter o direito de explorar os outros, para que eles possam se mostrar bonzinhos e obriguem Deus a recebê-los na bem aventurança eterna. Coitadinho, deve estar com uma fila enorme na porta. Se eu der esmola a um desses profissionais da mendicância, que ficam batendo de porta em porta ou com a mão estendida na calçada, o que vou fazer é ajudar a mantê-lo naquela situação indigna. Ser bom é ruim então. Melhor ensinar a pescar, dizem as ONGs, do que dar o peixe. Quem não concorda com isso é o próprio peixe, que acaba sendo comido de um jeito ou de outro.

Os que se acham muito bonzinhos esquecem que vivem à custa da morte alheia. A vida é má por natureza. Supor que um deus morreu para salvar o homem ajuda o 
FLÁVIO R. KOTHE

homem a crer que todos os que morrem entre seus dentes estão querendo salvá-lo. Na pior das hipóteses, acha que está dando a um ente inferior uma chance fazer um upgrade navegando em sua pança: deveria até ficar feliz por isso.

Uma vez um senhor idoso, quando por nós passava um caminhão carregado de cervejas, me disse com um suspiro: "Eu acho que bebi alguns caminhões destes." A vida tinha sido bem aproveitada, pensava ele. Morreria feliz. Pareceu-me estranho que ele tivesse um paradigma tão baixo de felicidade, sem pensar sequer que talvez os seus filhos tivessem passado necessidade por lhes faltar o que era gasto nos engradados. Quando viu um leve sorriso em meu rosto, ele achou que eu estivesse concordando e aplaudindo. Não me dei ao serviço de explicar. De nada adiantaria, era tarde demais. 